\title{
Irreconcilable Differences?
}

\section{An Analysis of the Standoff between the African Union and the International Criminal Court}

\author{
Mia Swart \& Karin Krisch*
}

\begin{abstract}
From initial African support for the establishment of the International Criminal Court to recent proposals that African states should withdraw from it, the article traces the history of the relationship between the African Union and the Court and the reasons for its deterioration. The discussion is focussed on the issue of immunity for sitting heads of state, which has emerged as a major sticking point between the two organisations. The disagreement is illustrated with reference to the ICC's efforts to prosecute the Kenyan President and his deputy. We examine the legal position on head-of-state immunity at international law, and proceed to evaluate the AU's proposal that the ICC should amend the Rome Statute to provide for immunity for sitting heads of state, as well as the amendment to the Protocol of the African Court of Justice and Human Rights, in light thereof.
\end{abstract}

Keywords: International Criminal Court, African Union, Kenya investigation, immunity, Heads of state.

\section{Introduction}

The establishment of the International Criminal Court (ICC or the Court) was the realization of the dreams of those who believed that, in order to prevent ongoing impunity, the international community should work together to establish a permanent international criminal tribunal. It was a dream shared not only by European and other Western states but also by African states.

Established amid great international fanfare in 2002, much was made of the fact that the ICC was the first permanent international penal tribunal. But it soon became evident that the court was not truly international or universal. ${ }^{1}$ As the Court's first prosecutor, Luis Moreno-Ocampo, focused investigation after investigation on African countries, this had an increasingly polarizing effect, reinforc-

* Mia Swart is Professor of International Law at the University of Johannesburg, South Africa. Karin Krisch is LLM candidate at the University of Johannesburg, South Africa. The authors thank Prof. Charles Jalloh for his insightful comments and guidance.

1 At present, a third of the countries in the United Nations, including some of the biggest like the United States and China, as well as a substantial number of smaller countries, like Syria and Sudan, have not ratified the Rome Statute. 
ing the fear that it would serve the West. It was entirely predictable that the ICC would soon be accused of neo-colonialism. ${ }^{2}$ African countries also felt that their sovereignty was threatened by the Court.

One of the most promising and exciting aspects of the creation of the ICC was the large-scale signing of the Rome Statute of the International Criminal Court, 17 July 1998 (Rome Statute) by African countries. At present Africa is the most represented region in the Assembly of States Parties (ASP). ${ }^{3}$ The consensusbased nature of the ICC did much to bolster its legitimacy. This was widely seen as a more acceptable model for establishing an international court than the model used to establish the ad hoc international criminal tribunals by Security Council fiat.

The relationship between the African Union (AU) and the ICC initially deteriorated in 2008 after an indictment was issued to arrest the Sudanese president Omar Al-Bashir. In the years since 2008, the relationship continued to deteriorate. By 2013, the tension between some African countries and the ICC reached a crisis point. The issue of head of state immunity has become the main point of contention between the two sides. Some believe the adversarial stance has been channelled through and encouraged by the AU. ${ }^{4}$ The AU has even asked its members to implement a policy non-cooperation with the ICC in respect of the arrest and surrender of particular suspects. ${ }^{5}$

This article will provide a brief history of the relationship between the AU and the ICC. It will outline the reasons for the souring of the relationship. We focus attention on the proposal that the ICC should amend the Rome Statute to provide for immunity for sitting heads of state. The amendment to the Protocol of the African Court of Justice and Human Rights will be criticised. The proposal by states such as Kenya to amend the Rome Statute to allow for immunity for sitting heads of state, in particular Kenyatta and Ruto, will, in our view, be a retrogressive measure since such an amendment will arguably be contrary to international law. It is worth noting that the case of Kenyatta and Ruto is unique in international criminal justice. Unlike other heads of state before international tribunals, Kenyatta and Ruto only assumed power after they became suspects before the ICC.

The question of whether sitting heads of state should be prosecuted for international crimes was one of the greatest points of disagreement in the recent standoff between the AU and the ICC. According to Article 27 of the Rome Stat-

2 See President Uhuru Kenyatta's speech during the Extraordinary Session of the Assembly of Heads of State and Government of the African Union in which he repeatedly referred to colonialism and imperialism. His speech is available at <www. scribd.com/doc/175602445/President Uhuru-Kenyatta-s-Speech-during-the-Extraordinary-Session-of-the-Assembly-of-Heads-of-Stateand-Government-of-the-African-Union-Addis-Ababa >

3 See website of the ICC available at <www.icccpi.int/en_menus/asp/states\%20parties/Pages/the \%20states\%20parties\%20to\%20the\%20rome\%20statute.aspx >.

4 See Global Justice 25 March 2014 available at <http://ciccglobaljustice.wordpress.com/2014/03/ 25/civil-society-defends-icc-at-african-union-summit/ >.

5 J. Mbaku, 'International Justice: The International Criminal Court and Africa', Brookings Institute, 2014. 
ute, it is clear that heads of state of member countries can be prosecuted. It will be argued that whereas customary international law on immunities may protect heads of state and senior state officials in respect of certain acts, it does not protect such officials from prosecution for international crimes. It will be asserted that the attempts and threats of African countries to withdraw from the ICC might have strategic value in terms of expressing an African position. However, such withdrawal will not lead to the achievement of the AU's own commitment to abolish impunity as expressed in its Constitutive Act. ${ }^{6}$

\section{Background to the Dispute between the AU and the ICC}

African states played a crucial role in the creation of the ICC, ${ }^{7}$ demonstrating their initial support for the Court through widespread ratification of the Rome Statute. Of the 122 States Parties, 34 are African, the largest regional grouping to have ratified the Statute. ${ }^{8}$ By 2013, the relationship soured dramatically, with African states repeatedly threatening to withdraw from the Court. One of the factors that strained the relationship is the ICC's perceived bias against Africa, with the indictment of sitting heads of African states emerging as a major point of contention.

African countries were initially supportive of the establishment of the ICC and were of the view that this would be a positive development in global governance. ${ }^{9}$ According to Murithi, the memory of the Rwandan genocide convinced many African countries of the need to support an international criminal justice regime such as the ICC. ${ }^{10}$ African countries also viewed the ICC as a way of preventing powerful countries from preying on weaker states. ${ }^{11}$ African states played an important role in the Court's ability to obtain 60 ratifications - the number that was required for the ICC treaty to enter into force and kick off its work in 2002. ${ }^{12}$ At the time African countries raised objections to the self-exclusion of powerful countries such as the United States from the Rome Statute.

The initial discontent of African states was caused primarily by the fact that they were the object of all of the ICC prosecutors' investigations. To date the Prosecutor has not initiated prosecutions against any country outside Africa.

6 See Art. 4(h) of the Constitutive Act of the African Union of 11 July 2000, which gives the AU the right "to intervene in a Member State pursuant to a decision of the Assembly in respect of grave circumstances, namely: war crimes, genocide and crimes against humanity". Art. 4(o) refers to "respect for the sanctity of human life, condemnation and rejection of impunity and political assassination, acts of terrorism and subversive activities".

7 M. du Plessis, 'The International Criminal Court That Africa Wants', Monograph 172 published by the Institute for Security Studies, 2010, pp. 5-6.

8 Id.

9 T. Murithi, 'The African Union and the International Criminal Court: An Embattled Relationship?', Institute for Justice and Reconciliation (IJR) Policy Brief, March 2013, p. 8.

10 Id.

11 Mbaku, 2014, p. 9.

12 C. Jalloh, 'Regionalising International Criminal Law', International Criminal Law Review, No. 9, 2009, pp. 446-447. 
Whereas it can be argued that all international criminal prosecutions are selective in nature (since it will always be impossible to prosecute every international crime committed in situations of large scale violations of human rights and humanitarian law), the Prosecutor's exclusive focus on Africa has disappointed and angered many who looked to the Court to provide universal and impartial justice. ${ }^{13}$ Moreover, the reasons provided by the ICC in explaining why it has not investigated situations outside Africa have been unconvincing. ${ }^{14}$ African states have accused the ICC of prosecuting crimes on the basis of political expediency that will not cause discomfort to the major funding states. ${ }^{15}$ Again, the ICC failed to convincingly respond to this charge.

In this respect, the ICC shows perfect historical continuity. The Court's two predecessors, the International Criminal Tribunal for the Former Yugoslavia (ICTY) and the International Criminal Tribunal for Rwanda (ICTR) were both deeply political creatures and were accused of being products of Western European-style racial and political prejudice. The idea of creating the ICTY was triggered by the shocking images of ethnic cleansing in the Balkans, reminiscent of the Holocaust. The sight of Europeans suffering in this way was simply too much to bear. Something had to be done and creating an ad hoc international criminal tribunal by Security Council fiat was the innovative result. The erection of the ICTR was even more politically controversial. It has often been argued that the ICTR was the West's way of compensating for the American Clinton administration's failure to intervene to stop the genocide. ${ }^{16}$

African states with poor domestic accountability mechanisms were clearly soft targets for a new court looking to establish its legitimacy. Why did African states ratify the Rome Statute in the first place? Several considerations likely pushed states one way or another. Poorer states might have seen the Rome Statute as a key to attract official development assistance. Non-governmental organizations might have pushed states one way or another in order to further their agendas. It has been argued that some states engaged in a simple rational choice analysis regarding ratification: whether ratification would marginalize domestic political competitors and benefit the sitting government. Internal politics, just as much as international power dynamics, provide an important framework for understanding whether and why a state ratified the Rome Statute. ${ }^{17}$

The issue of immunity arose in 2008, in the case of The Prosecutor v. Omar Hassan Ahmad al-Bashir, ${ }^{18}$ when the Prosecutor applied for an arrest warrant for

For more on the inherent selectivity in international criminal justice see A. Alamuddin, 'The Role of the Security Council in Starting and Stopping Cases at the International Criminal Court', in A. Zadar \& O. Bekou (Eds.), Contemporary Challenges for the International Criminal Court, British Institute of International and Comparative Law, London, 2014, pp. 109-111.

14 See Murithi, 2013, p. 3.

15 Id.

16 See S. Power, A Problem from Hell: America and the Age of Genocide, A New Republic, New York, 2003.

17 S. Prasanna, 'Did Some African States Ratify the Rome Statute to Marginalise Competitors?', available at <http://iccforum.com/forum/permalink/91/1198>

18 ICC-02/05-01/09. 
the sitting President of Sudan, Al Bashir, on charges of war crimes and crimes against humanity. The application was brought despite the fact that Sudan is not a party to the Rome Statute. Under Article 13(b) of the Statute the UN Security Council, acting under Chapter 7 of the UN Charter, may refer a situation to the Prosecutor where one or more of the crimes set out in Article 5 of the Statute (genocide, crimes against humanity, war crimes and the crime of aggression) appears to have been committed. The situation in Darfur was referred to the Prosecutor in terms of Security Council Resolution 1593 (2005), which states that:

the Government of Sudan and all other parties to the conflict in Darfur shall cooperate fully with and provide any necessary assistance to the Court and the Prosecutor pursuant to this resolution and, while recognising that States not party to the Rome Statute have no obligation under the Statute, urges all States and concerned regional and other international organisations to cooperate fully. ${ }^{19}$

The Security Council not only granted the ICC jurisdiction over the matter notwithstanding that Sudan is not a party to the Statute, it also obliged Sudan to cooperate with the Court and the Prosecutor, who would eventually demand the surrender of its head of state.

The AU Peace and Security Council (PSC) responded by adopting a resolution stressing the ICC's complementarity to national jurisdictions, and expressing its firm belief that the pre-trial chamber's approval of the warrant could undermine the delicately negotiated efforts of the AU and the United Nations to resolve the conflict in Sudan. ${ }^{20}$ Concern was expressed that the issuance of a warrant may threaten efforts to promote peace and reconciliation, leading to destabilization and further suffering for the people of Sudan. The Security Council was requested to defer the proceedings against al-Bashir under Article 16 of the Rome Statute, ${ }^{21}$ so as not to jeopardise ongoing regional peace efforts.

Notwithstanding the AU's concerns, the ICC pre-trial chamber (PTC) decided to issue the arrest warrant for al-Bashir on 4 March 2009, prompting the PSC to immediately issue a further communique lamenting the timing of the arrest warrant and restating its concern that the ICC process would seriously undermine ongoing efforts to achieve peace and security. ${ }^{22}$ The Security Council was again

19 SC Res. 1593 (2005), para. 2.

20 See Peace and Security Council Communique arising out of its 142nd Meeting, held on 21 July 2008 in Addis Ababa, Ethiopia PSC/MIN/Comm (CXLII) available at <www. iccnow. org/ documents/AU_142-communique-eng.pdf >.

21 Deferral of investigation or prosecution:

No investigation or prosecution may be commenced or proceeded with under this Statute for a period of 12 months after the Security Council, in a resolution adopted under Chapter VII of the Charter of the United Nations, has requested the Court to that effect; that request may be renewed by the Council under the same conditions.

22 Peace and Security Council Communique arising out if its 175th Meeting, held on 5 March 2009 in Addis Ababa, Ethiopia PSC/PR/Comm. (CLXXV) available at <www. peaceau. org/ uploads/ iccarrestwarranteng.pdf >. 
requested to exercise its powers of deferral over the situation and, once again, it failed to act upon the request. In light of the above, it is not surprising that at the 13th AU Summit of Heads of State on 3 July 2009 in Sirte, Libya, African leaders resolved not to co-operate with the ICC in securing the arrest of al-Bashir.

The Sirte resolution was perceived as a violation of the Rome Statute and a betrayal of Africa's commitment to end impunity for human rights atrocities. ${ }^{23}$ Even among the AU states the resolution was not wholeheartedly welcomed. Botswana publicly distanced itself from the resolution in a press release issued the day after the Summit, stating that it "does not agree with [the AU decision] and wishes to reaffirm its position that as a State Party to the Rome Statute on the International Criminal Court (ICC) it has treaty obligations to fully cooperate with the ICC in the arrest and transfer of the President of Sudan to the ICC". After finding itself at the receiving end of widespread criticism for its support of the resolution, South Africa also clarified its position at a press conference held after the Sirte resolution, affirming that it would co-operate with the ICC in the investigation and prosecution of crimes and in the execution of arrest warrants. ${ }^{24}$

The AU reiterated its stance of non-cooperation regarding al-Bashir's arrest warrant at its summit of 22 July 2010, where the following remarks were made by AU Chairperson and Malawian President Bingu wa Mutharika:

To subject a sovereign head of state to a warrant of arrest is undermining African solidarity and African peace and security that we fought for so many years [...] There is a general concern in Africa that the issuance of a warrant of arrest for [...] al-Bashir, a duly elected president, is a violation of the principles of sovereignty guaranteed under the United Nations and under the African Union Charter. Maybe there are other ways of addressing this problem. ${ }^{25}$

At around the same time as the 2010 Summit, al-Bashir travelled to Chad to attend a summit of the Community of Sahel-Saharan States. He has also travelled to Kenya, Djibouti, Nigeria, Uganda and the Democratic Republic of Congo without being arrested. ${ }^{26}$

The immunity debate was again highlighted in connection with the Situation in the Republic of Kenya, which arose when the announcement of the 2007 presidential election results sparked a wave of ethnic violence across the country, eventually leaving over 1,000 people dead. A coalition government was formed after AU mediators brokered a power sharing deal between incumbent President Mwai Kibaki of the Party of National Unity and Prime Minister Raila Odinga of the Orange Democratic Movement. The coalition agreed to initiate an investigation into the violence, and a commission of inquiry was established for this pur-

23 Du Plessis, 2010, p. 16.

24 Id.

25 Id., p. 18.

26 See C. Jalloh, M. du Plessis \& D. Akande, 'Assessing the African Union Concerns about Article 16 of the Rome Statute of the International Criminal Court', African Journal of Legal Studies, 2011, pp. 5-13. 
pose. The commission reported unprecedented and widespread acts of planned and also spontaneous violence throughout Kenya, recommending that a domestic tribunal be created to prosecute the instigators or alternatively, that a list of suspects be forwarded to ICC Prosecutor Moreno-Ocampo for possible investigation and prosecution. ${ }^{27}$

When the proposed bill to establish a tribunal was rejected by Kenyan lawmakers, ${ }^{28}$ a sealed envelope containing a list of suspects was delivered to the Prosecutor $^{29}$ and after further inaction by the Kenyan government, MorenoOcampo applied to the PTC for judicial authorisation to investigate the post-election violence. ${ }^{30}$ The request was granted in March 2010, authorising the Court's first proprio motu investigation of a situation. Summonses were issued to six individuals: Uhuru Muigai Kenyatta, Francis Kirimi Muthaura, Mohammed Hussein Ali, William Samoei Ruto, Henry Kiprono Kosgey and Joshua Sang. ${ }^{31}$ Charges were only confirmed for four, and eventually, the Prosecutor withdrew charges against one.

The Kenyan government challenged the admissibility of the cases, ${ }^{32}$ arguing that domestic legal reforms, including the new Kenyan Constitution, paved the way for Kenya to conduct its own prosecutions in relation to the post-election violence and that the cases were therefore inadmissible under Article 17(1)(a) of the Statute. ${ }^{33}$ The PTC rejected this argument on the basis that Kenya had failed to provide concrete evidence that it had initiated any investigations or prosecutions into the matters before the Court, ${ }^{34}$ a finding that was subsequently confirmed by the Appeals Chamber. ${ }^{35}$

27 Report of the Commission of Enquiry into Post Election Violence 473, available at <http:// reliefweb.int/sites/reliefweb.int/files/resources/15A00F569813F4D549257607001F459D-Full_ Report.pdf>.

28 T. Miller-Sporrer, 'Kenya Parliament Rejects Bills Establishing Election Tribunal', The Jurist, available at <http://jurist.org/paperchase/2009/02/kenya-parliament-rejects-bills.php〉.

29 ICC Press Release on 9 July 2009, 'ICC Prosecutor Receives Sealed Envelope from Kofi Annan on Post-Election Violence in Kenya', available at <www.icc-cpi.int/en_menus/icc/situations and cases/situations/situation icc 0109/press releases/Pages/pr436.aspx>.

30 ICC-01/09 Request for authorisation of an investigation pursuant to Art. 15 available at <www. icc-cpi.int/iccdocs/doc/doc785972.pdf>.

31 Situation on the Republic of Kenya ICC-01/09-01/11, Decision on the Prosecutor's Application for Summonses to Appear for William Samoei Ruto, Henry Kiprono Kosgey and Joshua Arap Sang, 8 March 2011, available at <www.icc-cpi.int/iccdocs/doc/doc1037044.pdf>.

32 See C. Jalloh, 'Situation in Republic of Kenya, No. ICC-01/09-02/11-274; Judgment on Kenya's Appeal of Decision Denying Admissibility', American Journal of International Law, Vol. 106, 2012, p. 119.

33 Art. 17(1)(a) provides that:

(1) Having regard to paragraph 10 of the Preamble and Article 1, the Court shall determine that a case is inadmissible where:

(a) The case is being investigated or prosecuted by a State which has jurisdiction over it, unless the State is unwilling or unable genuinely to carry out the investigation or prosecution.

34 Decision of the Pre Trial Chamber available at <www.haguejusticeportal.net/Docs/ICC/Kenya/ RulingonAdmissibilityMuthaura,AliandKenyatta.pdf> and <www. haguejusticeportal. net/ Docs/ ICC/Kenya/RulingonAdmissibility/Ruto,KosgeyandSang.pdf $>$. Decision of the Appeals Chamber, available at <www.icc-cpi.int/iccdocs/doc/doc1223134.pdf > 
Following national elections in March 2013, Kenyatta became President and Ruto Vice-President of Kenya. At the AU Assembly two months later, the view was expressed that the ongoing prosecution of Kenyatta and Ruto undermined the sovereignty of the people of Kenya (who expressed their democratic will to be represented by the two accused) and threatened the country's process of reconciliation.

Reiterating the points initially raised by the Kenyan Government regarding the ICC's complementary jurisdiction, the AU adopted a decision requesting the ICC to refer the Kenyatta and Ruto cases back to Kenya. ${ }^{36}$

Having failed to secure trials in Kenya, the government applied to have Kenyatta and Ruto excused from continuous presence at trial, ${ }^{37}$ to enable the ongoing performance of their functions. The PTC granted the requests on condition that both accused be physically present at the Court for the following proceedings:

i the entirety of the opening statements of all parties and participants;

ii the entirety of the closing statements of all parties and participants;

iii when victims present their views and concerns in person;

iv the entirety of the delivery of judgment in the case;

$\mathrm{v}$ the entirety of the sentencing hearings (if applicable);

vi the entirety of the sentencing (if applicable);

vii the entirety of the victim impact hearings (if applicable);

viii the entirety of the reparation hearings (if applicable); and

ix any other attendance directed by the Chamber. ${ }^{38}$

Following the suspension by the Appeals Chamber of the PTC decision relieving Ruto from the obligation to attend all the proceedings of his trial, a chain of correspondence was initiated between the AU and the ICC. Hailemariam Desalegn, Chairperson of the AU and Nkosazana Dlamini-Zuma, Chairperson of the AU Commission wrote to the President of the ICC, conveying the decision of the 21st ordinary session of AU Heads of State and Government requesting the referral of the Kenyan cases to domestic courts, and expressing concern that proceedings before the ICC are adversely affecting the ability of Kenyan leaders to discharge their duties. In the letter the President is requested to allow Kenyatta and Ruto to "choose the sessions they wish to attend" in accordance with their constitutional obligations as leaders of Kenya's popularly elected government. ${ }^{39}$

In a somewhat patronising response the ICC President Song points out that a decision of the Assembly of the AU does not amount to a request to the ICC in accordance with the Court's legal framework, noting that no formal request for deferral of the Kenya cases to domestic courts had been made to the relevant Criminal Court (ICC) Doc. Assembly/AU/13(xxi) adopted at the 21st ordinary session 26-27 May 2013.

37 ICC-01/09-01/11 of 18 June 2013, available at <www.icc-cpi.int/iccdocs/doc/doc1605793.pdf > and ICC-01/09-02/11 of 18 October 2013 available at <www. icc -cpi. int/ iccdocs/ doc/ doc1667182.pdf>.

39 AU letter BC/U/1657.09.13 of 10 September 2013. 
Chambers since the initial admissibility challenge. Song explained that the Presidency has no legal powers to consider the issues raised, and that they must be formally brought before the relevant Chambers by a party or participant to the case (which would exclude the AU as it is neither). Alternatively, States or organisations may seek leave to submit observations to the Chamber under Rule 103 of the ICC's Rules of Procedure and Evidence. Given repeated attempts to have the trials moved, referred or held in absentia it is perhaps not surprising that on 5 September 2013, the Kenyan Parliament voted to withdraw from the ICC. ${ }^{40}$ The opposition party described this as an "ill-considered recommendation" which urged the executive branch make Kenya the first country to withdraw from the ICC. ${ }^{41}$ The Court has since allowed Ruto to be absent from certain parts of his trial, subject to specified conditions. ${ }^{42}$

In light of the ongoing tensions flowing from the situation in Kenya, the AU convened an extraordinary summit in October 2013 to debate the future of Africa's relationship with the Court. ${ }^{43}$ Essentially the decision made at the summit called for two things: the adoption of a policy for not prosecuting sitting heads of state and for the cases against Kenyatta and Ruto to be deferred in accordance with Article 16 of the Rome Statute. The result was a set of resolutions condemning the prosecution of sitting heads of state and calling on all states in the AU to shield their heads of state from prosecution before national and international courts, and to propose amendments to the Rome statute. ${ }^{44}$

But the AU summit decision does not change the obligation of African member states of the ICC under the Rome Statute. This means that Kenyatta and Ruto remain bound by the existing rules of the ICC, which extends to the prosecution of sitting heads of state. Significantly, President Kenyatta would be in breach of ICC obligations if he fails to appear before the Court.

Jalloh emphasises that irrespective of whether Kenya withdraws from the ICC, its obligations to support the crucial justice process started under the Rome Statute will continue to exist. ${ }^{45}$ In spite of Kenya' sovereign right to withdraw from the Rome Statute, it is clear that withdrawal will only take effect one year after a state has notified the UN Secretary General of its intention to withdraw. ${ }^{46}$ Withdrawal can also not be used to undermine ongoing investigations. ${ }^{47}$

In May 2014 Kenya suggested amendments to the Rome Statute in a number of areas. Key among suggested amendments was that "serving Heads of State,

40 Proceedings of the National Assembly available at <www. parliament. go. ke/ plone/ national assembly/business/order-paper/thursday-september-05-2013-at-2.30-p.m/view .

41 C. Jalloh, 'Kenya Should Reconsider Proposed Withdrawal from the ICC', The Jurist, 13 September 2013 available at <www.jurist.org/forum/2013/09/charles-jalloh-kenya-icc.php>.

42 See <www.icc-cpi.int/iccdocs/doc/doc1756313.PDF>, p. 3, reference to Transcript, ICC-01/0901/11-T-72-ENG, pp. 66-68.

43 S. Ayele Dersso, 'The AU's Extraordinary Summit Decisions on Africa-ICC Relationship', 28 October 2013 available at <www. ejiltalk.org/the-aus-extraordinary-summit-decisions-on-africa-iccrelationship >.

44 Ext/Assembly/AU/Dec. 1 (October 2013).

45 Jalloh, 2013.

46 In accordance with Art. 127(1) of the Rome Statute.

47 Id. 
their deputies and anybody acting or who is entitled to act as such may be exempt from prosecution during their current term of office. Such an exemption may be renewed by the Court under the same conditions". ${ }^{48}$ In addition, Kenya wants the Rome Statute to explicitly state that ICC trials can take place in the absence of the accused persons. The proposal also intends to stretch the definition of complementarity by providing that ICC can only act if national and regional courts fail to act. This will allow for regional courts like the East African Court of Justice and the proposed African Court of Justice and Human Rights (African Court) to take precedence over the ICC. The Rome Statute currently recognises only the national courts. Kenya also wants to see changes introduced providing that the Office of the Prosecutor and third parties should be held accountable for offences against the administration of justice. In addition Kenya proposed the establishment of the Independent Oversight Mechanism "for inspection, evaluation and investigation of the Court, in order to enhance its efficiency and economy" ${ }^{49}$

The proposed amendments to the Rome Statute have already been opposed by at least 40 civil society organisations that have written to the AU expressing fear of the creation of "a sphere of impunity for high-level perpetrators 'and the creation of 'an incentive for such perpetrators to hold on to power indefinitely". 50 Prominent Africans such as former UN Secretary General Kofi Annan and Archbishop Emeritus Desmond Tutu have weighed in on the debate, pleading with African countries to cooperate with the ICC. ${ }^{51}$

A draft resolution seeking a deferral from the Security Council of the ICC cases against Kenyatta and Ruto was put to the vote in the Security Council on 15 November 2013 and failed to pass. ${ }^{52}$ Seven of the fifteen Security Council members voted in favour of the draft resolution on the postponement of the trials of Kenyatta and Ruto. Eight members abstained. ${ }^{53}$

In a significant regional development, the Protocol on Amendments to the Protocol on the Statute of the African Court of Justice and Human Rights was

48 See <www.jfjustice.net/kenya-amendment-proposals-to-the-rome-statute-received-by-the-un/>, 20 March 2014.

49 See Art. 112 of Submission by the Republic of Kenya on Amendments to Rome Statute of The International Criminal Court for Consideration by the Working Group on Amendments, 14 March 2014. See also Kenya Amendment Proposals to Rome Statute received by the UN, Journalists for Justice, 20 March 2014, available at <www.jfjustice.net/kenya-amendment-proposalsto-the-rome-statute-received-by-the-un/>.

50 W. Menya, 'Fresh Push to Save Uhuru, Ruto from ICC,' Daily Nation, 14 June 2014, available at <www. nation. co. ke/ news/ politics/ Fresh -push -to -save -Uhuru -and -Ruto -from -ICC/ -/ 1064/ 2348938/-/k6ecsoz/-/>.

51 S. Macgregor, 'Tutu Chides Kenya, Sudan Call for Africa to Withdraw from ICC', Business Day, 11 October 2013, available at <www.bdlive.co.za/africa/2013/10/11/tutu-chides-kenya-sudancall-for-africa-to-withdraw-from-icc $>$.

52 UN Doc. S/PV.7060. This was a meeting to vote on a draft resolution (S/2013/660) on the ICC deferral of President Kenyatta and his deputy, the resolution was not adopted, with only seven Council members voting in favour and the remaining eight members abstaining. See <www. securitycouncilreport. org/atf/cf/\%7B65BFCF9B-6D27-4E9C-8CD3-CF6E4FF96FF9\%7D/s_pv_ 7060.pdf>.

53 Security Council: bid to defer International Criminal Court cases of Kenyan leaders fails, UN News Centre available at <www.un.org/apps/news/story.asp?NewsID=46499\#.U6vEEbcaKpo . 
adopted at the 23rd Summit of the AU held in Malabo, Equatorial Guinea in June 2014, granting immunity to heads of state and senior government officials from prosecution for crimes such as those under the jurisdiction of the ICC, which immunity endures for the tenure of their office. ${ }^{54}$ Clearly this amendment conflicts with the Rome Statute and it has accordingly attracted widespread criticism, with Amnesty International expressing the view that it represents a step backwards in the fight against impunity and undermines the integrity of the African Court. ${ }^{55}$ El Hadj Guisse, a judge of the African Court, has expressed disappointment over this decision by African leaders. He believes it will dilute the work of the planned new African Court. ${ }^{56}$

\section{Immunity: The Precedent Set by the International Criminal Tribunals}

Can African states justify their argument that sitting heads of states should be exempted from ICC prosecution? This section will briefly outline the long standing position with regard to head of state immunity. The section will briefly discuss the developments and innovations in the law of immunity brought about by the international criminal tribunals over the last two decades. It will be argued that there are many indications that a rule of customary international law is developing in terms of which the immunity of sitting heads of state is not recognized in respect of international crimes.

The law of immunities in international law with regard to criminal acts that do not qualify as international crimes is well-established. It has long been clear that customary international law requires that heads of state enjoy both functional and personal immunity. One of the two forms of immunity is immunity ratione personae, also known as 'personal' immunity from the jurisdiction of national courts of foreign states. This extensive form of immunity can be wide enough to cover both public and private acts, and includes immunity from criminal jurisdiction. According to Cassese, personal immunity covers personal activities of an official, including immunity from arrest and detention, immunity from criminal jurisdiction and immunity from the civil and administrative jurisdiction of the host state. ${ }^{57}$ The rationale for personal immunity is that for the sake of the smooth conduct of international relations certain persons should be protected by personal immunity. This rule with regard to immunity was recognised in Pinochet 3 when Lord Browne-Wilkinson noted that "the immunity enjoyed by a head of state in power [...] is a complete immunity attaching to the person of the head of state". ${ }^{58}$ Although the existence of personal immunity for those who commit-

See <www.ijrcenter.org/2014/07/02/african-union-approves-immunity-for-heads-of-state-inamendment-to-african-court-of-justice-and-human-rights-statute/ $>$.

55 See <http:// amnesty. org/ en/ news/ au -summit -decision -backward -step -international -justice -2014-07-01>.

56 L. Louw-Vaudran, 'The Hague "Targets Africa”, Mail \& Guardian, 18 July 2014, available at <http://mg.co.za/article/2014-07-17-the-hague-targets-africa〉.

57 A. Cassese, International Law, Oxford University Press, New York, 2005.

58 Pinochet (No. 3) [1999] 2 All E.R. 97. 
ted international crimes can be criticised, it is clear from international case law that personal immunity for those who committed international crimes remains intact.

Prominent decisions of the International Court of Justice such as Congo $v$. Belgium ${ }^{59}$ and Germany v. Italy ${ }^{60}$ have confirmed that under customary international law diplomats and heads of states enjoy personal immunity with regard to acts performed in the fulfilment of their functions. The traditional rationale for the personal immunity of these officials is that such immunities prevent states from interfering with the fulfilment of foreign states' sovereign activities in their territories. ${ }^{61}$ Congo v. Belgium went one step further by holding that an arrest warrant to arrest senior state officials for crimes against humanity breaches the law of immunity under international law. It was clearly stated in this case that heads of state, heads of government and ministers of foreign affairs, enjoy immunity from jurisdiction in other states, both civil and criminal. ${ }^{62}$

Since Congo v. Belgium involves charges of crimes against humanity against the former foreign minister of the Congo it does not create precedent for the immunity of heads of state in matters that do not involve international crimes. This judgment has been extensively criticized on the basis that it was not sensitive to the progressive developments in international law and international criminal law and that the traditional law on immunity does not apply in cases of crimes against humanity. ${ }^{63}$ The dissenting opinions of Judge Christine van den Wyngaert $^{64}$ in DRC v. Belgium and Judge Cancado Trindade ${ }^{65}$ in Germany v. Italy have been particularly influential in this regard.

The second form of immunity is immunity ratione materiae or 'functional' immunity. This covers the official acts of all state officials and is determined by reference to the nature of the acts rather than the particular office of the official who performed them. This immunity is derived from the office of the individual concerned and, according to the ICJ, is enjoyed by heads of state, heads of government, foreign ministers and, possibly, a limited category of other very highranking state representatives. Once the individual has left office, he or she ceases to be entitled to such immunity.

But do sitting heads of state charged with having committed international crimes enjoy functional immunity? Since the commission of an international crime cannot be regarded as an official state function such an act must always be

59 Arrest Warrant Case (Democratic Republic of the Congo v. Belgium), 14 February 2002 ICJ.

60 Case Concerning Jurisdictional Immunities of the State (Germany v. Italy - Greece Intervening), 3 February 2012 ICJ.

61 P. Gaeta, 'Does President Al Bashir Enjoy Immunity from Arrest?', JCIJ, Vol. 7, No. 2, 2009, p. 320.

62 ICJ Reports, 2002, pp. 3, 20; 128 ILR, p. 76.

63 S. Wirth, 'Immunity for Core Crimes? The ICJ's Judgment in the Congo v. Belgium Case', EJIL, Vol. 13, No. 4, 2002; M. Swart, 'DRC v. Belgium: A Step Backwards?', SA Public Law, Vol. 17, No. 2, 2002, pp. 305-319.

64 Dissenting Opinion of Judge Van den Wyngaert. Arrest Warrant Case (Democratic Republic of the Congo v. Belgium), 14 February 2002 ICJ.

65 Dissenting Opinion of Judge Cancado Trindade, Jurisdictional Immunities of the State (Germany $v$. Italy: Greece intervening). 
regarded as a private act by the person concerned. In light of the fact that committing an international crime is not a state function, neither the perpetrator nor the state of which the perpetrator is a national can claim functional immunity. ${ }^{66}$ This principle was recognised in the Bouterse ${ }^{67}$ case before the Amsterdam Court of Appeal.

The rule against immunity for international crimes is also often referred to as the principle of irrelevance of official capacity. The irrelevance of official capacity before international criminal courts has become entrenched in international law since the International Military Tribunal at Nuremberg. The statutes of many of the international criminal courts and tribunals, including the ICTY, ${ }^{68}$ ICTR $^{69}$ and Special Court for Sierra Leone ${ }^{70}$ have set aside head of state immunity as well as other forms of immunity to which senior state officials have traditionally been entitled. It is therefore hardly credible that African states such as Kenya could claim that they did not expect that heads of state could be subjected to the jurisdiction of these courts.

Another important question is whether heads of state that are still in office enjoy personal immunity. In the Ghadaffi ${ }^{71}$ case before the Cour de Cassation in Paris it was suggested by the Avocat général that the general rule on irrelevance of official capacity, in the case of commission of international crimes, would not apply to Heads of State in office. ${ }^{72}$ It is respectfully submitted that the Avocat général made a mistake by considering as functional immunity what is in reality the personal immunity of Heads of State. The decision is incorrect, because no evidence supports the idea that an exception to the exclusion of functional immunity for international crimes has evolved relating to Heads of State in office. The Avocat général referred to the absence of practice concerning trials of sitting Heads of State. In particular, he considered that the rule excluding immunity, although it was contained in several conventional instruments has never been implemented. But the fact that there was little indication of state practice (and therefore custom) when this case was decided in 2001 does not mean that a customary rule could not currently be in the process of developing. The prevailing view in the academic literature is that sitting heads of state should not enjoy functional immunity for international crimes. And the increase in the amount of

66 Advisory Report on the Immunity of Foreign State Officials 17, Advisory Committee on Issues of Public International Law, 2001, available at <http://cms.webbeat.net/ContentSuite/upload/cav/ doc/cavv-report-nr-20-immunity_foreign_officials.pdf $\rangle$.

67 LJN: AA8395, Amsterdam Court of Appeal (Gerechtshof), 20 November 2000, consideration 4.2 available at <www.rechtspraak.nl>.

68 Art. 7(2) of the Statute of the ICTY.

69 Arts. 6(2), 29(3) and (4) of the Statute of the ICTR recognises functional immunity but it is clear that no immnuty is provided to cover private acts.

70 Art. 6(2) of the Statute of the Special Court for Sierra Leone. The agreement establishing the Special Tribunal for Lebanon does not contain any clause removing immunities. Since the Extraordinary Chamber on the Courts of Cambodia (ECCC) is trying Cambodians the issue of international immunities is not of relevance for this court.

71 Arrêt of the Cour de Cassation, 13 March 2001, No. 1414, p. 1.

72 See S. Zappala, 'Do Heads of State in Office Enjoy Immunity from Jurisdiction for International Crimes?', European Journal of International Law, 2001, pp. 595-612. 
case law emanating from both national and international courts is a strong indication that state practice is rising to a point where one can say that a rule of custom is developing.

\section{Evaluation of the African Union's Proposals on Immunity}

The immunity dispute takes place within the context of much wider disagreement between African states and the ICC about the nature and functioning of the Court. The exclusive indictment of sitting heads of state has served to exacerbate perceptions of a deep anti-African bias at the Court. From the early days of the ICC's existence, commentators have gone as far as to call the Court a neo-imperialist tool of Western hegemony, deliberately targeting Africans as a means of avoiding conflict with Western powers. ${ }^{73}$ This is a sentiment shared by many African leaders, such as Rwandan President Paul Kagame, who has dismissed the Court as a forum created to prosecute Africans and others from poor countries. ${ }^{74}$ Certainly the indictment of sitting heads of African states while the Security Council fails to refer situations in Iraq or Syria to the Court makes it difficult not to draw the conclusion that Africa is viewed as a soft target for prosecutions.

If, as African states charge, the non-recognition of head of state immunity is a manifestation of anti-African bias then the attitude of the Court as reflected in the jurisprudence of the Court should be examined. The Trial Chamber made it clear that Kenyatta was excused only for the purpose of enabling him to fulfil his duties as President of Kenya. The Trial Chamber begins its decision regarding Kenyatta's request for conditional release as follows:

Whenever a national trauma is inflicted upon a country, the eyes of the nation invariably turn to one person - the executive head of state or government-with questions and for answers and demands for solutions and hopes of future safety. It is so with natural disasters or massive accidents or intentional acts of terror. But there is much more that the executive head of state or government must do in good faith, often unsung and out of sight, to prevent national traumas. And, beyond the management and prevention of emergencies, he or she does so much more. Indeed, the functions of the executive head of state of the average nation will be too numerous to list here. Hence, the sovereign functions of an executive head of state or government are significantly different from those of any other citizen... ${ }^{75}$

This statement is significant in that it shows an appreciation of the traditional arguments made to justify the immunity of heads of state in the context of

73 D. Hoile, 'The International Criminal Court: Europe’s Guantánamo Bay?', Africa Research Centre, 2010, pp. 43-50.

74 See <www. ugee. com/ dos-donts -in -uganda-about-ugada-352/ dos-donts -photo-gallery-about ugada-393/1958-kagame-brands-icc-as-new-form-of-imperialism >.

75 Decision on Defence Request for Conditional Excusal from Continuous Presence at Trial, Prosecutor $v$. Uhuru Muigai Kenyatta, ICC-01/09-02/11, 18 October 2013. 
exempting diplomats and heads of states from 'ordinary' criminal and civil prosecution. It is reminiscent of the arguments that state sovereignty and international sovereignty and comity requires diplomatic immunity. It can be argued that this language is not entirely appropriate in the context of international crimes that violate ius cogens norms deemed to be so egregious that the international community has agreed that perpetrators of such crimes should prosecuted or extradited. It is submitted that the rhetoric of the Trial Chamber does not fit the context of international crimes. The Trial Chamber does not offer a justification for exempting heads of state from prosecution and the obligation to attend trial. From a pragmatic point of view, however, it seems that by using this language the Trial Chamber is trying to find a compromise between the demands of the Rome Statute and the actual position the accused finds himself in. It also showed that the Court was sensitive to the peace versus justice debate in international criminal law. The fact that the Court allowed Kenyatta and Ruto to be absent from trial during certain parts of the proceedings shows that the tribunal took their arguments and requests seriously. It also show a willingness to engage constructively with the arguments presented by African leaders.

However by excusing Kenyatta and Ruto from attending parts of their trials, the Court is departing from a strict principled approach to head of state immunity. A principled approach should not only be followed regarding the question of whether to prosecute or not but relates to the method of prosecution as well and would entail not making any concessions to the accused as compared to accused persons of a lower official status.

According to Lamony of the Coalition for the ICC some of the African delegations complained about the text of the immunities clause in the Rome Statute because it is in conflict with existing domestic laws which provide that a Head of State or senior government official can be held accountable for international crimes. ${ }^{76}$ Ironically Kenya for example has removed immunity for international crimes for sitting heads of states in its domestic law implementing the Rome Statute. ${ }^{77}$ South Africa similarly removed such immunity in its domestic law. ${ }^{78}$ The Kenya situation clearly illustrates that bringing domestic law in line with interntaional law does not guarantee adherence to the principles contained in the Rome Statute.

The immunity debate has highlighted anxieties around the national security implications of prosecuting sitting heads of state. At the Twelfth Assembly of States Parties annual meeting in November 2013, Kenyan Attorney-General Githu Muigai said the court was playing 'Russian roulette' with his country by bringing cases against Kenyatta and Ruto. He stated: "Our country is the lynchpin in the peace and security involving more than 250 million people from Djibouti to eastern Democratic Republic of Congo and everybody in between", ${ }^{79}$ referring to Kenya as an ally of the West in the battle against militant Islam and a "pillar of 
security" in Eastern Africa, which was being threatened by the prosecutions. Hence the prosecutions not only threaten national security, but also undermine international efforts in the fight against terrorism.

While the prosecution of sitting heads of state certainly has a disruptive effect on national governance, it is difficult to ascertain whether efforts to combat international terrorism would necessarily be endangered. It is not always easy to draw the line between genuine concerns around national and international security, and the more sinister motive of shielding the most powerful from prosecution. Furthermore the true extent of the AU's commitment to bring an end to impunity is not clear.

Kenya proposed the following amendment to Article 27 of the Rome Statute:

Notwithstanding paragraph 1 and 2 [of art. 27] above, serving Heads of State, their deputies and anybody acting or is entitled to act as such may be exempt from prosecution during their current term of office. Such an exemption may be renewed by the Court under the same conditions. ${ }^{80}$

The ASP avoided paying much attention to this proposed amendment, on the basis that such amendments can only be determined three months after their notification to states parties. ${ }^{81}$ The amendment to Article 27 remains under consideration, while other amendments to the ICC Rules and Procedures were adopted $^{82}$ to allow for an accused to be excused from presence at trial or to give testimony through video technology in certain circumstances. It is interesting to note that Rule 134 quater of the amendments refers to the possibility of excusal from presence at trial due to extraordinary public duties 'at the highest national level', perhaps indicating an intention to regulate, rather than abolish, the prosecution of the highest ranking officials.

\section{Are African Solutions Effective?}

After the appointment of the current ICC Prosecutor, Fatou Bensouda from the Gambia there were hopes that her appointment will usher in a new era of impartiality. It was also thought that the appointment of an African Prosecutor would go some way towards appeasing the Court's detractors, but so far there are no indications that her approach is very different to that of her predecessor. Commenting on criticism of the Court, Bensouda has remarked that "what offends me the most when I hear about this so-called Africa bias is how quick we are to focus on the words and propaganda of a few powerful, influential individuals and to

80 See note 44.

81 Coalition for the International Criminal Court Report on the 12th Session of the Assembly of States Parties at 20.

82 <www.icc-cpi.int/iccdocs/asp_docs/Resolutions/ASP12/ICC-ASP-12-Res7-ENG.pdf>, 30 June 2014. 
forget about the millions of anonymous people who suffer from their crimes" 83 The Prosecutor should however be sensitive to the concerns of those who feel that Africa is being unfairly targeted and steer clear of dismissive language such as describing legitimate criticism as 'propaganda'.

The sticking point of immunity can be viewed as part of a broader political backlash to the perceived double standards of the Court in selecting individuals for indictment. This is also indicated by the resurgence in Pan-Africanist rhetoric, emphasising the need to find 'African solutions to African problems' instead of turning to foreign institutions, which have so far yielded unsatisfactory results.

The internal divisions in Africa over the ICC were demonstrated during a recent conference entitled 'International Justice, Reconciliation and Peace: the ICC and beyond' held in Senegal. ${ }^{84}$ The conference clearly showed the divide between those African countries that want Africa to find its own 'indigenous' solutions and those countries that believe that African justice systems are not independent and are not equipped to try perpetrators. ${ }^{85}$

The ICC is, in our view, currently the only international institution capable of effective prosecution of international crimes on international scale. The track record of the judicial institutions of the African Union is disappointing. The record of the African Court on Human and Peoples' Rights ("African Court") has been particularly uninspiring. The African Court has only heard a handful of cases and is not currently equipped to take on prosecutions of this kind. ${ }^{86}$ It is highly unlikely that a newly created African Court of Justice and Human and Peoples' Rights would be more effective. The East African Court of Justice has so far only arbitrated disputes between states. Kenya's suggestion that it extend its jurisdiction to hear international criminal cases will not only stretch its mandate beyond its capacity but is simply unrealistic in light of the general inefficiency of this court. The ICC represents much more than a court.

Both the AU and the ICC share the mandate and responsibility to address impunity on the African continent and to ensure accountability for gross violations of human rights and international crimes. In discussing the AU's budding peace and security architecture, Jalloh emphasises that African governments undertook in the Constitutive Act of the AU as well as in the Peace and Security Protocol to engage other governments and civil society, international organizations, for example, the UN, as well as other external entities that could assist it to realize its human security objectives. He writes: "In relation to the Court, these 18 January 2013, available at <www.nytimes.com/2013/01/19/world/africa/challenging-startfor-bensouda-as-chief-prosecutor-in-the-hague.html?pagewanted=all\&_r=0 >.

85 In light of the lack of political will and resources that will be required to set up a regional court to prosecute international crimes, Jalloh argues that an Africa-responsive ICC is a better option. See C. Jalloh, 'The African Union and the International Criminal Court: The Summer of Our Discontent(s)', The Jurist, 6 August 2010.

86 Trying individuals for serious crimes is distinct from the African Court's present work and will place unique burdens and expenses on the court, such as the need for systems of witness protection, evidence collection, and detention of accused. 
instruments open up an avenue for mutually beneficial AU-ICC cooperation on issues ranging from technical cooperation to concrete measures combating impunity." 87

\section{Conclusion}

The AU position need not conflict with that of the ICC. It may be extreme to caricature the African position on the ICC as being motivated by a desire to shield African despots from prosecution. The AU and the ICC share important goals and objectives. Like the ICC, the AU, in its Constitutive Act and its Peace and Security Protocol, ${ }^{88}$ aim to prevent impunity for international crimes. ${ }^{89}$ For the AU these goals should not remain merely rhetorical. Even if African countries should decide to withdraw from the ICC, individually or en masse, African countries who were state parties to the Rome Statute would still be held to their obligations thereunder for some time. As members of the international community, such African states would have obligations to prosecute heads of state for international crimes in terms of ius cogens norms and customary international law. For the sake of the universality of criminal justice, it is important that African countries remain part of the ICC.

The ICC is nothing less than a ground-breaking, historical and diplomatic achievement. One of the most remarkable features of the permanent court is the fact that it was not imposed by Security Council Resolution but built by the consensus of states. African states themselves therefore have a strong interest in the functioning of the system they actively helped create. The ICC system shows respect for the principle of ius cogens - the principle that some crimes are so serious that the entire international community has an interest in prosecuting such crimes. The ICC's emphasis on complementarity means that the ICC may have positive spill-over effects into domestic justice systems.

The proposal by Kenya that Article 27 of the Rome Statute should be amended to provide immunity for heads of state should be opposed by African governments and African civil society. It is important to emphasise that exempting heads of state from criminal liability before the ICC is contrary to international law as well as the rule of law. ${ }^{90}$

87 Jalloh, 2009, p. 458.

88 Protocol Relating to the Establishment of the Peace and Security Council of the African Union (Peace and Security Protocol) adopted in Durban, South Africa on 9 July 2002.

89 Such principles are contained in Art. 4 of the Constitutive Act of the AU. These principles include the principle that the AU may intervene in a member state pursuant to a decision of the Assembly of Heads of State and Government of the Union in respect of grave crimes such as war crimes, genocide and crimes against humanity. See C. Murungu \& J. Biegon (Eds.), Prosecuting International Crimes in Africa, Pretoria University Law Press, 2011, p. 53.

90 See C. Jalloh, 'Reflections on the Indictment of Sitting Heads of State and Government', African Journal of Legal Studies, Vol. 7, 2014, p. 56. See Prosecutor v. Uhuru Muigai Kenyatta, ICC-01/0902/11, Trial Chamber V(A), 'Decision on Defence Request for Conditional Excusal from Continuous Presence at Trial', 18 October 2013, Separate Opinion of Judge Chile Eboe-Osuji, para. 30. 
Disrespect for the principle of the irrelevance of official capacity for heads of state (former or sitting) can do tremendous damage to the Rome Statute system. In light of the established international law on the functional immunity of heads of state charged with international crimes and the argument that a customary international law is developing to this effect, African countries should not be supported to swim against the stream of international criminal justice. For African countries to withdraw from the ICC will not make them any more powerful in the international arena.

The fact that the ICC is a political creature is not surprising. What is surprising, is that the Court does not care more deeply about its legitimacy and credibility. Because of the severity of the sanctions imposed by criminal law, it is important that the institutions imposing the sanctions enjoy legitimacy. For a court that took 50 years to come into existence, one would have expected it to tread more carefully in selecting its prosecutions. The neutral and distant manner of the current ICC President Song does little to instill confidence in African leaders that the ICC will now be more responsive to the concerns of African states.

The ICC should manage its inevitably political character with far more sensitivity and concretely show even handedness by indicting a number of accused from outside Africa. Prosecutions in Columbia, Iraq, Syria and Israel have been proposed. For the sake of the victims, the Court should get on with its core business of actively prosecuting those most responsible for the commission of the crimes under its jurisdiction wherever they occur. To retain the moral integrity of the ICC prosecutions must be based on the principle that "the most serious crimes of concern to the international community as a whole must not go unpunished". 